\title{
Cryosphere: a kingdom of anomalies and diversity
}

\author{
Vladimir Melnikov ${ }^{1,2,3}$, Viktor Gennadinik ${ }^{1}$, Markku Kulmala ${ }^{1,4}$, Hanna K. Lappalainen ${ }^{1,4,5}$, Tuukka Petäjä ${ }^{1,4}$, and \\ Sergej Zilitinkevich ${ }^{1,4,5,6,7,8}$ \\ ${ }^{1}$ Institute of Cryology, Tyumen State University, Tyumen, Russia \\ ${ }^{2}$ Industrial University of Tyumen, Tyumen, Russia \\ ${ }^{3}$ Earth Cryosphere Institute, Tyumen Scientific Center SB RAS, Tyumen, Russia \\ ${ }^{4}$ Institute for Atmospheric and Earth System Research (INAR), Physics, Faculty of Science, \\ University of Helsinki, Helsinki, Finland \\ ${ }^{5}$ Finnish Meteorological Institute, Helsinki, Finland \\ ${ }^{6}$ Faculty of Radio-Physics, University of Nizhny Novgorod, Nizhny Novgorod, Russia \\ ${ }^{7}$ Faculty of Geography, University of Moscow, Moscow, Russia \\ ${ }^{8}$ Institute of Geography, Russian Academy of Sciences, Moscow, Russia
}

Correspondence: Hanna K. Lappalainen (hanna.k.lappalainen@helsinki.fi)

Received: 17 November 2017 - Discussion started: 12 January 2018

Revised: 20 March 2018 - Accepted: 26 March 2018 - Published: 8 May 2018

\begin{abstract}
The cryosphere of the Earth overlaps with the atmosphere, hydrosphere and lithosphere over vast areas with temperatures below $0{ }^{\circ} \mathrm{C}$ and pronounced $\mathrm{H}_{2} \mathrm{O}$ phase changes. In spite of its strong variability in space and time, the cryosphere plays the role of a global thermostat, keeping the thermal regime on the Earth within rather narrow limits, affording continuation of the conditions needed for the maintenance of life. Objects and processes related to cryosphere are very diverse, due to the following basic reasons: the anomalous thermodynamic and electromagnetic properties of $\mathrm{H}_{2} \mathrm{O}$, the intermediate intensity of hydrogen bonds and the wide spread of cryogenic systems all over the Earth. However, these features attract insufficient attention from research communities. Cryology is usually understood as a descriptive discipline within physical geography, limited to glaciology and permafrost research. We emphasise its broad interdisciplinary landscape involving physical, chemical and biological phenomena related to the $\mathrm{H}_{2} \mathrm{O}$ phase transitions and various forms of ice. This paper aims to draw the attention of readers to the crucial importance of cryogenic anomalies, which make the Earth atmosphere and the entire Earth system very special, if not unique, objects in the universe.
\end{abstract}

\section{Introduction}

Nowadays the Earth system is facing the so-called "Grand Challenges". The rapidly growing population needs fresh air and water, more food and more energy. Thus humankind suffers from climate change, deterioration of the air, water and soils, deforestation, acidification of ocean waters and biodiversity losses. The Grand Challenges are threatening the security of upcoming societies. As stated in the Earth System Manifesto, humankind only has a 40-year window to avoid a collapse of the Earth system (https://www.atm.helsinki.fi/ peex/images/manifesti_peex_ru_hub2.pdf).

Especially strong environmental changes are observed and are expected to go on during the next decades in North Eurasia and the Arctic Ocean (IPCC, 2014). The rate of the changes in the Arctic Region is higher than elsewhere in the world (Smith et al., 2015; IPCC, 2013). Furthermore, the threats from climate change and deterioration of the environment are redoubled by restricted natural resources, unrestrained migration tendencies, and uncertainties in political and socio-economic developments (Smith, 2010).

The totality of environmental problems in relation to human activities in North Eurasia (the area north of $45^{\circ} \mathrm{N}$, including the Arctic Ocean and between the Atlantic and $\mathrm{Pa}$ cific Oceans in terms of latitude) is addressed in the recently launched international program "Pan-Eurasian Experiment" 
(PEEX) aimed at responding to the Grand Challenges faced by European countries, as well as Russia and China (Lappalainen et al., 2014; Kulmala et al., 2015). The PEEX Science Plan (Lappalainen et al., 2016) focuses on the Polar and Arctic regions and, specifically, on the cryosphere in the context of modern challenges of the North Eurasian environment.

Historically, cryosphere research has been developed in the frame of physical geography with the major focus on glaciology and permafrost research. The present paper attracts the attention of the broad geoscience community of physicists, chemists, biologists and, prospectively, astrophysicists to topical problems related to ice, snow and cold in a wider interdisciplinary context, beyond the present conventional understanding (see above).

\section{Cryosphere and cryogenic anomalies}

Cold regions and natural phenomena related to cold are often described with terms using the prefix "cryo", meaning "cold". The totality of phenomena on the Earth related to or linked with snow, ice or ice-like products (such as gas hydrates) comprises the Earth's cryosphere (Fig. 1) - a complex synergic system with self-organised constituents, which maintains the heat and mass exchange with the environment and spreads over the atmosphere, the hydrosphere, the lithosphere and the biosphere (Melnikov and Gennadinik, 2011).

The large extent of cryogenic objects, their variability in space and time, as well as the discontinuity of the cryosphere, have inspired development of special management technologies. Such technologies, taking into account the stabilising and bio-protective effects of ice, rooted in specific properties of ice, have become applicable to the areas outside high latitude and low temperature regions (Melnikov et al., 2010).

Recent investigations of the cryosphere have yielded discovery and scientific description of a number of unique natural objects and phenomena called "cryogenic anomalies". Below we consider examples of recently investigated cryogenic anomalies, tentatively divided into six groups: ice structure, glaciation, ocean, atmospheric ice and water, biota and cold and rates of processes.

\section{Ice structure}

Being a compositionally simple material, ice possesses diverse anomalous properties. It can exist in seventeen phase states, out of which eleven states are clearly expressed. This diversity is expressed in physico-chemical and biological processes, and in the types of precipitation: one type for rain, eight types for snow, and two mixed water-ice types (Eisenberg and Kauzman, 1975). There are paradoxically different properties brought together in ice: it is at the same time elastic and plastic, crystalline and amorphous, semiconducting and dielectric, lighter than water but harder than steel
(Maeno, 1988). With its crystals built uniquely by hydrogen bonds, ice provides a standard for estimating these bonds. The complexity of the ice structure and its non-equilibrium phase transitions are sufficient for self-organising synergetic behaviour and formation of stable macroscopic objects, like the classical snowflakes or drop clusters in atmospheric clouds (Shavlov et al., 2011).

\section{Glaciation}

Glaciation is the most impressive cryogenic phenomenon on Earth. Currently, ice covers more than $10 \%$ of the Earth's surface, but the area of glaciation was much larger in some periods of the Earth's history. Traces of early Proterozoic glaciations (Huron, about 2300 myr ago) are found on all modern continents, which is evidence of global glaciation, even taking into account the drift of continents. About 300 myr ago a large part of Gondwana was covered by ice (John, 1979).

The exact cause of glaciations remains debatable but their cyclic nature is beyond doubt. The complex pattern of glacial cycles cannot be explained solely by orbital forcing of eccentricity, obliquity, and precession that change in Milankovitch cycles (Milanković, 1939), but also correlates with global geological events.

Glaciation obviously reduces the area of rocks exposed to wind erosion and causes progressive $\mathrm{CO}_{2}$ increase though a more active respiration of bacteria, which recycle dead organics at less active photosynthesis. This, in turn enhances the greenhouse effect of the atmosphere and thus increases the temperature. Due to this negative feedback, oscillations in the cryosphere correlate with phases of global greenhouse gas and temperature cycles. There is also a positive feedback that controls ice surfaces waxing and waning (Le Hir et al., 2008). In particular, the increasing albedo may have been responsible for the strongest glaciation about $800 \mathrm{myr}$ ago, the "Snowball Earth" (Kirschvink et al., 1997). The observed recent shrinking of areas covered by glaciers is often attributed to anthropogenic factors, which became a real geological force in the 20th century (Vernadsky, 1965). The true extent of this effect will be clear in the near future.

The very existence of ice sheets changes the composition and physical properties of the lithosphere, the hydrosphere, and the atmosphere. Moving ice transports great amounts of material and, at the same time, preserves the entrained objects. During glaciations, crust becomes denser, volcanism increases, ice sheets extended to the troposphere change the atmospheric composition and circulation, sea level falls and climate changes. After the ice retreats, the formerly frozen territories experience isostatic rebound and terrain smoothing, changes in landscapes, such as formation of rivers and lakes and changes in biota, such as species composition. 
(a)

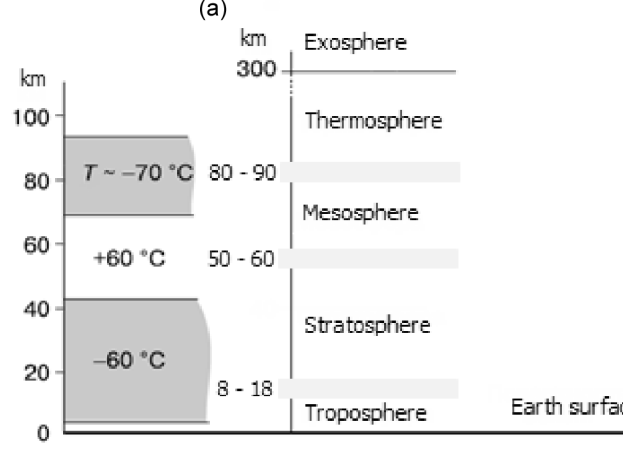

(b)

Figure 1. The Earth's cryosphere: from (a) the uppermost atmosphere, to (b) $5 \mathrm{~km}$ below Earth's surface, where ice exists as hydrates at positive temperatures (Melnikov and Gennadinik, 2011).

\section{Permafrost}

Formation of permafrost is the principal consequence of glaciation. Remnants of permafrost that formed during the last glacial event currently cover a large area. The stability of permafrost is one of the greatest challenges, first of all for Russia, where it occupies $65 \%$ of national territory, but also for the global climate-biosphere system, due to the strong links between the permafrost and boreal forests, tundra, peatlands, rivers and other water reservoirs. Objects and phenomena associated with permafrost to a large extent determine the sustainability of the Siberian climate-biosphere system (taiga), the conditions of land use and lives of the population. The ice barriers dramatically change the natural flow of water and material in mid latitudes, change hydrological regimes and create traps for gases. The methane traps cause jet degassing of hydrocarbons (Melnikov et al., 1997), which in turn can lead to cooling of rocks, formation of gas hydrates, accumulation of large amounts of methane and to methane explosions. The latter causes significant changes in both underwater and land topography (see Fig. 2).

On land, such explosions may produce giant craters which subsequently transform into lakes (see Fig. 3). Tracking such processes over large areas in real time with proper resolution in space, as well as the early warning of expected gas explosions, are important tasks envisaged in the PEEX Science Plan (Lappalainen et al., 2016).

Permafrost leaves imprints in the gravity field, as in the case of the Hudson Bay, where the gravity field is lower than elsewhere at this latitude (Tamisiea et al., 2007), possibly as a consequence of the North American glaciation. About 75000 years ago ice $(3.7 \mathrm{~km}$ thick in the Hudson Bay area) covered most of the present northern US and Canada, which has left a large depression. On the contrary, the gravity field over $1 \mathrm{~km}$ thick permafrost (such as in eastern Siberia) can reach $50 \mathrm{mGal}$. On the geological time scale, this field can

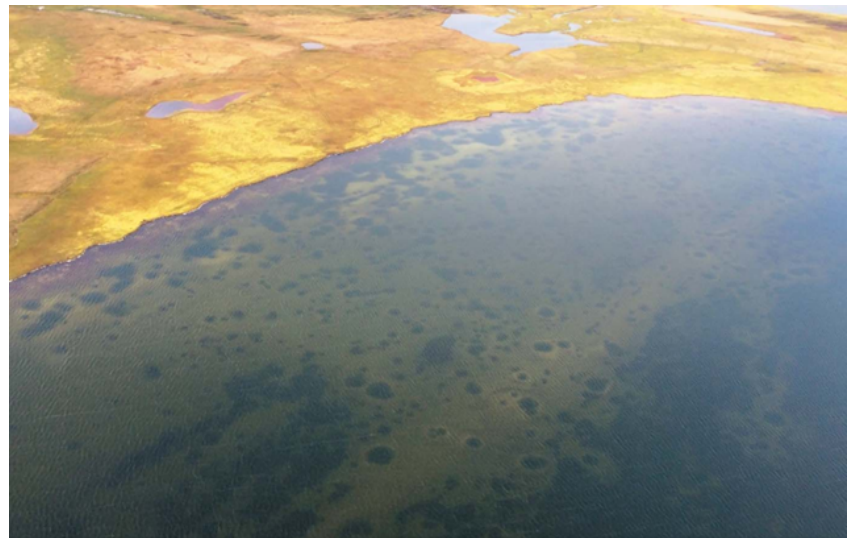

Figure 2. Photo of a lake on the Yamal Peninsula showing numerous craters from gas explosions on the lake bottom (Bogoyavlensky, 2015).

influence the homeostasis of living organisms and their speciation.

\section{Ocean}

Oceanic ice is a major controlling factor of the global climate as it screens heat and mass transfer in both vertical (across the air-water interface) and horizontal directions. Warm currents, such as that of North Atlantic, move mainly along the ocean surface due to thermal expansion of warm water. Glaciers on the way of warm currents can melt rapidly because the ice should not necessarily reach the seafloor to stop them, but can only be commensurate with the surface water layer.

Another "Great Challenge" addressed in the PEEX Science Plan is the ongoing change in the Arctic Ocean ice cover, exposing increasingly larger and longer-exposed icefree areas (Hayes et al., 2014; Schaefer et al., 2014; Döscher 


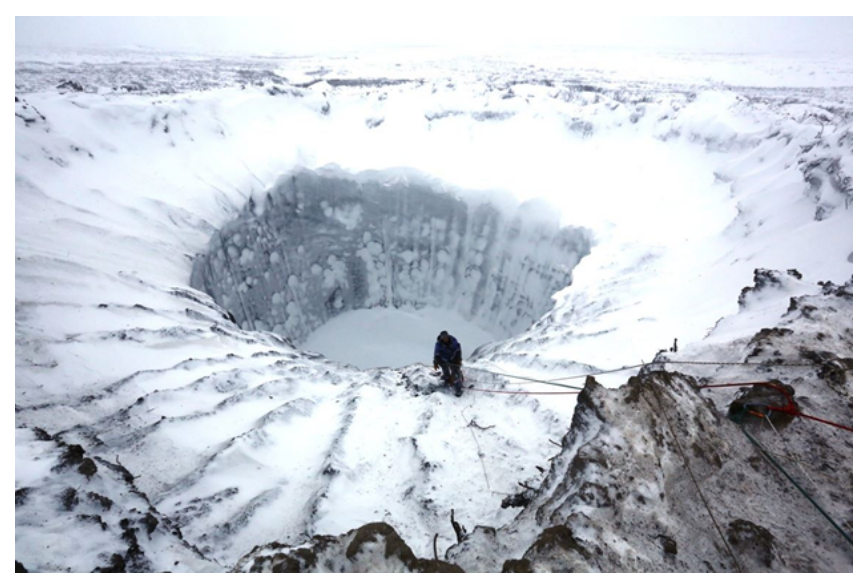

Figure 3. New crater produced by gas explosion on the Yamal Peninsula in 2014 (Leybman et al., 2015; photograph by Vladimir Pushkarev).

et al., 2014). This tendency is favourable for exploring and transporting northern Siberian oil and gas, comprising about $25 \%$ of total world resources (Yenikeyeff and Krysiek, 2007).

\section{Atmospheric ice and water}

Ice has very high heat capacity, specific heat of melting and dielectric constant. The phase transition forms shields of different types and scales from the gas hydrates stored in permafrost to the ice sheets that cover the entire Antarctic continent and affect the global climate and evolution of life. In the global Earth system, the cryosphere acts as a temperature stabiliser, due to the exceptional thermal inertia of ice and water occupying a large percentage of the Earth's surface.

The Earth's atmosphere contains a large amount of water in the form of vapour, liquid and ice, which all influence the planetary heat budget. Moreover, the atmosphere acts as a "thermal shield", aggregating the water molecules into ice particles and thus regulating water on Earth, vital for the maintenance of life. The phase transitions of atmospheric ice produce diverse, sudden effects and various precipitation types: rain, ice, drizzle, moist snow, snow, sleet or hail. In the dry troposphere, the air cools down adiabatically at $0.98^{\circ} \mathrm{C}$ per $100 \mathrm{~m}$. Hence, condensation of what was originally nearly saturated water vapour has already started a few hundred metres above the surface. Along with sublimation, this leads to heat release, which affects temperature profiles and other properties of the atmosphere. Generally, condensation of pure water vapour starts at $400-500 \%$ supersaturation (e.g. Pruppacher and Klett, 1997). However, condensation in the real atmosphere starts shortly after relative humidity exceeds $100 \%$, due to the presence of solid or liquid aerosol particles acting as condensation nuclei, but can even occur below $100 \%$ in some cases (Kulmala et al., 1997). Similarly, ice nucleation is initiated upon nuclei like dust particles, biological particles etc., including anthropogenic aerosol particles (e.g. Hoose and Möhler, 2010; Atkinson et al., 2013). Thus, the air pollution facilitates formation of ice crystals and cloud droplets, and therefore affects the air temperature and precipitation processes and its spatiotemporal variability (Rosenfeld et al., 2014). The aerosol-cloud-climate interactions (see e.g. Kulmala et al., 2011), as well as air pollutionweather-climate interactions (Ding et al., 2016; Petäjä et al., 2016) have been, and are still, under rigorous investigations.

\section{Biota and cold}

A number of facts of evolutionary biology would be unexplainable without cryosphere. Contrary to the common thinking, the existence of life is compatible with negative temperatures. For example, photosynthesis is quite possible at temperatures below $0^{\circ} \mathrm{C}$ (Kramer and Kozlowski, 1960). For billions of years, the cryosphere assured the level of environmental stability that is required for the development of life. The mean annual air temperatures on the Earth were naturally maintained near the ice-water transition point. Ice, like water, possesses exceptional thermostatic properties and is thus a very strong stabiliser of the temperature regime, along with the wide spread of ice over the Earth's surface. The heat capacity of water $\left(4.183 \mathrm{~kJ}(\mathrm{~kg} \mathrm{~K})^{-1}\right)$ is five times the mean heat capacity of soil, and its volumetric heat capacity is 3300 times that of air. The high heat capacity of ice $\left(2.06 \mathrm{~kJ}(\mathrm{~kg} \mathrm{~K})^{-1}\right)$ is comparable with that of water, which makes the ice-snow-water system the Earth's largest repository of solar energy. The phase change point has additional (likewise abnormal) thermal stability: the specific heat of ice melting is five times higher than in gold (332 against $\left.66.2 \mathrm{~kJ} \mathrm{~kg}^{-1}\right)$ and is higher than in mercury by a factor 28 , for example (Melnikov and Gennadinik, 2011).

Permafrost contains organic matter in the form of biogenic gases, products of biodegradation or as ancient viable bacteria. In Russia, the evidence of bacteria in permafrost was obtained in the late 19th century, together the discovery of mammoths in northern Siberia and during studies of soil in the Russian Far East. Novel information about bacterial communities has been obtained from studies of Antarctic permafrost. Cyanobacteria, with an age of about $500 \mathrm{kyr}$, were discovered in the "Vostok" station ice cores at a $3600 \mathrm{~m}$ depth (Osokin, 2003).

Many microorganisms are stable against freezing and not only survive but grow at negative temperatures. More than $10 \%$ of water in organic tissue remains unfrozen at temperatures below $-20^{\circ} \mathrm{C}$. Many basic processes in microbial, soil, geophysical and cosmological systems are associated with cooling and ice-water phase changes. Ribosome activity is often more successful at low temperatures, which may be the evidence that life could have originated in cold conditions (Vlassov et al., 2005). 
Life processes can remain active at below $0{ }^{\circ} \mathrm{C}$ in capillaries and on ice surface in permafrost. Micro-organisms can exist in media with low dimensionality ( 2 or less), such as liquid films and capillaries filled with super-cooled water. The porous structure of the environment ensures the transport of nutrients and life waste (Möhlmann, 2009).

Even comparatively minor heating to $50-60{ }^{\circ} \mathrm{C}$ leads to denaturation of proteins and can stop the operation of a living system, while freezing even to the near-absolute zero temperatures does not change the configuration of biomolecules, so that the life functions can resume after thawing. Enzymes that regulate metabolism in organisms show similar behaviour (Dethier and Villee, 1971).

It is still unclear how and why the metazoans originated about a billion years ago. The sufficient amount of oxygen required has been commonly explained by its gradual photosynthetic accumulation in the atmosphere. However, origination of metazoans may have been due to the higher concentration of oxygen in cold water. The origin of the skeletal organisms at the Proterozoic-Phanerozoic boundary was possibly favoured by the calcium carbonate release of organisms at high oxygen availability. The oxygen enrichment in oceans at the Vendian-Cambrian boundary may have resulted from glaciation and water cooling, thus increasing gas solubility and favourable water circulation patterns. Note that the first giant organisms appeared precisely during this cooling event. Furthermore, gigantism, associated with specific heat exchange, is known to be typical of polar biota. Biotic and cooling events were closely related all over the Phanerozoic. The major Jurassic and the latest Cretaceous extinctions occurred during stages of cold climate (John, 1979).

\section{Typical rates of processes}

Natural objects are characterised by their typical scales in time and space. Common sense suggests that temporal and spatial scales change similarly, which implies that typical change rates are not overly variable. However, this rule does not work for the cryosphere, which can be either the accelerator or decelerator of various processes (Melnikov et al., 2013). For instance, paleo-bacteria preserved under ice shields remain viable for millions of years. Ice slows down biotic processes due to the following properties:

- low dielectric and magnetic susceptibility, which reduces electromagnetic fields;

- high stiffness, which resists mechanical impacts;

- low permeability, which decelerates mass transport;

- high heat capacity and anomalous specific heat of melting, which damp temperature variations.

Hence, interaction between an object and its environment in cryosphere is basically restricted bt weak gravity effects and very slow diffusion. The capability of ice to decelerate biological processes has practical uses: freezing of organs or storage of seeds, not to mention household refrigerators. Similar mechanisms protect the biota of Antarctic paleolakes, such as Lake Vostok, hidden under kilometres-thick ice that maintains its sustainable thermal regime (Thoma et al., 2008).

On the contrary, processes on the surface of ice or icebearing systems are often faster than usual due to the formation of electrolytes, chemical reactions, and accelerated transport. "Ice fingers of death" is an example of a very rapid process with extremely high gradients of physical parameters in the vicinity of cryogenic objects. This phenomenon (also known as brinicles, brine icicles or ice stalactites) develops in shallow water beneath the sea ice, mainly in the southern high latitudes, in the form of slowly rotating jets of extremely cold, saline (and therefore heavy) surface water sinking down to the ocean floor (Martin, 1974). The point is that the formation of sea ice at very low air temperatures is associated with the decomposition of calcium bicarbonate into $\mathrm{CO}_{2}$ and $\mathrm{CaCO}_{3}$. Then $\mathrm{CO}_{2}$ releases into the air, whereas slowly rotating jets of cold dense surface water sink down to the seafloor and propagate downslope, leaving frozen footprints with entrapped bottom-dwelling sea animals.

Cryogenic phenomena developing at various rates are presented in the log-log space-time coordinates in Fig. 4 showing an extremely wide range of scales. Some objects, such as paleo-bacteria, which survived in ice for over half a million years, or the "ice fingers of death", fall beyond the scope of any particular science. To emphasise their multidisciplinary nature, these objects are marked by two colours, indicating the relevant pairs of disciplines.

\section{Cryodiversity and its role in the Earth system}

The Earth's cryosphere spreads from the oceanic depths reaching $\sim 5 \mathrm{~km}$ from the boundary between the atmosphere and outer space (called Karman line) at $\sim 100 \mathrm{~km}$ above the sea level. The cryospheres of the Earth and other planets with their satellites actually comprise the cryosphere of the Solar System with its radius of $\sim 100$ au, where the density of solar wind (radiated plasma) is high. Thus, the terrestrial cryosphere is an object among a diversity of planets and other large objects in the Solar System, which differ in their distance to the Sun, rotation rates and orbiting paths with the respective diurnal and annual cycles, chemical compositions and presence or absence of atmosphere. Some planets of the Solar System and their satellites store great amounts of ice, much more than the Earth, both in absolute values and relative to the mass of the respective celestial bodies. Recent extraterrestrial missions have demonstrated impressive cryogenic processes and phenomena on various planets and satellites (Komarov and Isaev, 2010). 


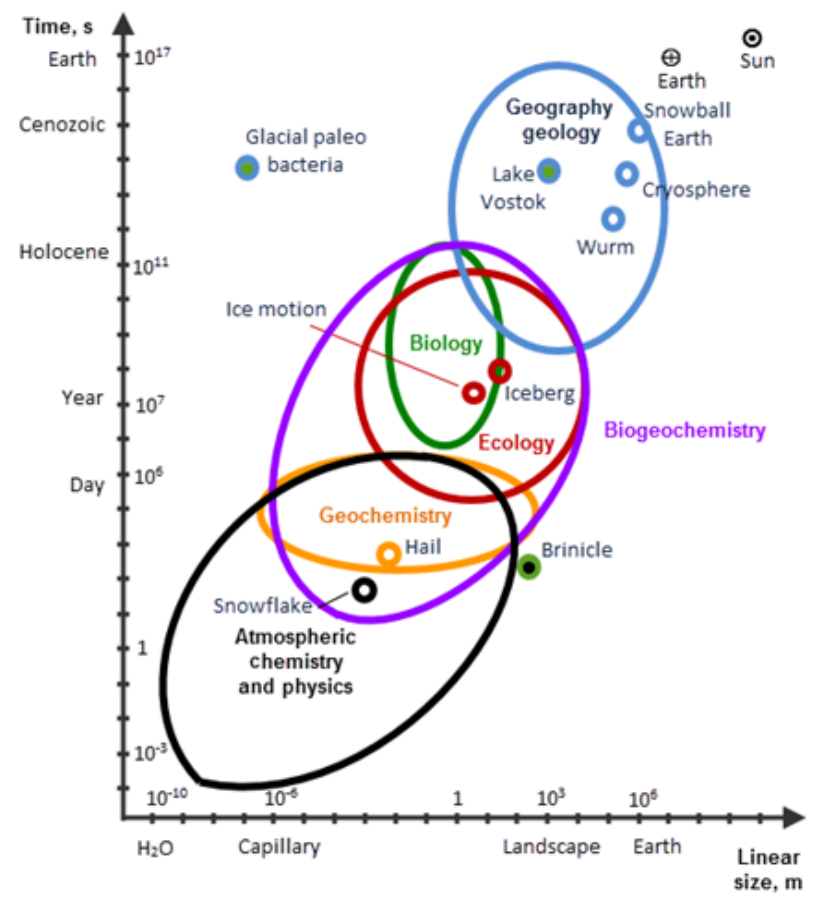

Figure 4. Log-log space-time diagram of cryogenic phenomena of different nature. Large ellipses or circles with different colours identify various sciences. Small circles show various objects of the cryosphere. The Earth and the Sun are shown to illustrate the range of scales.

\section{Cryogenic objects in the Solar system}

Historically, the Earth's cryosphere was investigated in the scope of exploration of the high-latitude or mountain regions characterised by cold climate, large stocks of ice and snow and strong thermal effects of $\mathrm{H}_{2} \mathrm{O}$ phase transitions. Those investigations were performed in the conceptual framework of geographical disciplines, such as glaciology or permafrost science. Their first priority was the description, quantification and inventory of phenomena, with comparatively little attention paid to concrete features of background physical, chemical and biological processes. Such an approach, although motivated by immediate practical purposes, limits our knowledge of the cryosphere to its present state and its geological past.

In view of ongoing climate change and massive anthropogenic deterioration of the environment, being able to predict the near future of the Earth's cryosphere in its capacity as the major stabiliser of the Earth climate and environment becomes critical. To this end, a leap is needed from the currently dominant descriptive approach to the process-based approach, unifying investigation of the totality of cryogenic phenomena from molecular to planetary scales (see Fig. 4) in an interdisciplinary science, cryology, armed with all necessary methods of geosciences, physics, chemistry and biology.

\section{Concluding remarks}

Ice has very high heat capacity, specific heat of melting and dielectric constant. The phase transition forms shields of different types and scales from the gas hydrates stored in permafrost to the ice sheets that cover the entire Antarctic continent and affect the global climate and evolution of life. In the global Earth system, the cryosphere acts as a temperature stabiliser, due to exceptional thermal inertia of ice and water that occupy a large part of the Earth's surface.

Data availability. Our conclusions are not deduced from specific datasets but resulted from analysing information from numerous papers listed in the references.

Competing interests. The authors declare that they have no conflict of interest.

Special issue statement. This article is part of the special issue "Pan-Eurasian Experiment (PEEX)". It is not associated with a conference.

Acknowledgements. The authors acknowledge support from the Academy of Finland via the Center of Excellence in Atmospheric Sciences and the project ABBA no. 280700 (2014-2017); the Nordforsk via CRAICC and CRAICC-PEEX projects; and the Russian Science Foundation via projects no. 15-17-20009 (2015-2018) and no. 15-17-30009 (2015-2018). Constructive comments by Veli-Matti Kerminen are especially appreciated. Vladimir Melnikov, Viktor Gennadinik and Sergej Zilitinkevich acknowledge support from bilateral project ClimEco no. 314 798/799 (2018-2020) funded by the Academy of Finland and Russian Foundation for Basic Research. Sergej Zilitinkevich acknowledges support from the Academy of Finland project ABBA no. 280700 (2014-2017); and Russian Science Foundation projects no. 15-17-20009 (2015-2018), no. 15-17-30009 (2015-2018), and no. 18-55-11005 (2018-2020).

Edited by: Imre Salma

Reviewed by: two anonymous referees

\section{References}

Atkinson, J. D., Murray, B. J., Woodhouse, M. T., Whale, T. F., Baustian, K. J., Carslaw, K. S., Dobbie, S., O’Sullivan, D., and Malkin, T. L.: The importance of feldspar for ice nucleation by mineral dust in mixed phase clouds, Nature, 498, 355-358, 2013.

Bogoyavlensky, V.: Gas Blowouts on the Yamal and Gydan Peninsulas, GeoExPro, London, UK, 12, No. 5, 74-78, 2015.

Dethier, C. A. and Villee, V. G.: Biological Principles and Processes, Saunders, Philadelphia, USA, 1009 pp., 1971. 
Ding, A. J., Huang, X., Nie, W., Sun, J. N., Kerminen, V.-M., Petäjä, T., Su, H., Cheng, Y. F., Yang, H. Q., Wang, M. H., Chi, X. G., Wang, J. P., Virkkula, A., Guo, W. D., Yuan, J., Wang, S. Y., Zhang, R. J., Wu, Y. F., Song, Y., Zhu, T., Zilitinkevich, S., Kulmala, M., and Fu, C. B.: Enhanced haze pollution by black carbon in megacities in China, Geophys. Res. Lett., 43, 2873-2879, https://doi.org/10.1002/2016GL067745, 2016.

Döscher, R., Vihma, T., and Maksimovich, E.: Recent advances in understanding the Arctic climate system state and change from a sea ice perspective: a review, Atmos. Chem. Phys., 14, 1357113600, https://doi.org/10.5194/acp-14-13571-2014, 2014.

Eisenberg, D. and Kauzman V.: Structure and properties of water, Gidrometeoizdat, Leningrad, Russia, 280 pp., 1975.

Hayes, D. J., Kickligher, D. W., McGuire, A. D., Chen, M., Zhuang, Q., Yan, F., Melillo, J. M., and Wullschleger, S. D.: The impacts of recent permafrost thaw on land-atmosphere greenhouse gas exchange, Environ. Res. Lett., 9, 045005, https://doi.org/10.1088/1748-9326/9/4/045005, 2014.

Hoose, C. and Möhler, O.: Heterogeneous ice nucleation on atmospheric aerosols: a review of results from laboratory experiments, Atmos. Chem. Phys., 12, 9817-9854, https://doi.org/10.5194/acp-12-9817-2012, 2012.

IPCC: Climate Change 2013: The Physical Science Basis. Working Group I Contribution to the Fifth Assessment Report of the Intergovernmental Panel on Climate Change, edited by: Stocker, T. F., Qin, D., Plattner, G.-K., Tignor, M., Allen, S. K., Boschung, J., Nauels, A., Xia, Y., Bex, V., and Midgley, P. M., Cambridge University Press, Cambridge, UK and New York, NY, USA, 2013.

IPCC: Climate Change 2014: Impacts, Adaptation, and Vulnerability. Part B: Regional Aspects, Contribution of Working Group II to the Fifth Assessment Report of the Intergovernmental Panel on Climate Change, edited by: Barros, V. R., Field, C. B., Dokken, D. J., Mastrandrea, M. E., Mach, K. J., Bilir, T. E., Chatterjee, M., Ebi, K. L., Estrada, Y. O., Genova, R. C., Girma, B., Kissel, E. S., Levy, A. N., MacCracken, S., Mastrandrea, P. R., and White, L. L., Cambridge University Press, Cambridge, UK and New York, NY, USA, 2014.

John, B. S. (Ed.): The winters of the world. Earth under the Ice Ages, edited by: John, B. S., David and Charles, Newton Abbot, London, North Pomfret (Vt), UK and New York, NY, USA, 1979.

Kirschvink, J. L., Ripperdan, R. L., and Evans, D. A.: Evidence for a large-scale reorganization of Early Cambrian continental masses by inertial interchange: true polar wander, Science, 277, 541-545, 1997.

Komarov, I. A. and Isaev, V. S.: Cryology of Mars and other Solar system planets, Scientific World, Moscow, Russia, 232 pp., 2010.

Kramer, P. J. and Kozlowski, T. T.: Physiology of trees, McGrawHill, 642 pp., New York, USA, 1960.

Kulmala, M., Laaksonen, A., Charlson, R. J., and Korhonen, P.: Clouds without supersaturation, Nature, 388, 336-337, 1997.

Kulmala, M., Asmi, A., Lappalainen, H. K., Baltensperger, U., Brenguier, J.-L., Facchini, M. C., Hansson, H.-C., Hov, Ø., O'Dowd, C. D., Pöschl, U., Wiedensohler, A., Boers, R., Boucher, O., de Leeuw, G., Denier van der Gon, H. A. C., Feichter, J., Krejci, R., Laj, P., Lihavainen, H., Lohmann, U., McFiggans, G., Mentel, T., Pilinis, C., Riipinen, I., Schulz, M., Stohl, A., Swietlicki, E., Vignati, E., Alves, C., Amann, M., Ammann, M., Arabas, S., Artaxo, P., Baars, H., Beddows, D. C. S., Bergström, R., Beukes, J. P., Bilde, M., Burkhart, J. F.,
Canonaco, F., Clegg, S. L., Coe, H., Crumeyrolle, S., D’Anna, B., Decesari, S., Gilardoni, S., Fischer, M., Fjaeraa, A. M., Fountoukis, C., George, C., Gomes, L., Halloran, P., Hamburger, T., Harrison, R. M., Herrmann, H., Hoffmann, T., Hoose, C., Hu, M., Hyvärinen, A., Hõrrak, U., Iinuma, Y., Iversen, T., Josipovic, M., Kanakidou, M., Kiendler-Scharr, A., Kirkevåg, A., Kiss, G., Klimont, Z., Kolmonen, P., Komppula, M., Kristjánsson, J.-E., Laakso, L., Laaksonen, A., Labonnote, L., Lanz, V. A., Lehtinen, K. E. J., Rizzo, L. V., Makkonen, R., Manninen, H. E., McMeeking, G., Merikanto, J., Minikin, A., Mirme, S., Morgan, W. T., Nemitz, E., O’Donnell, D., Panwar, T. S., Pawlowska, H., Petzold, A., Pienaar, J. J., Pio, C., Plass-Duelmer, C., Prévôt, A. S. H., Pryor, S., Reddington, C. L., Roberts, G., Rosenfeld, D., Schwarz, J., Seland, Ø., Sellegri, K., Shen, X. J., Shiraiwa, M., Siebert, H., Sierau, B., Simpson, D., Sun, J. Y. Topping, D., Tunved, P., Vaattovaara, P., Vakkari, V., Veefkind, J. P., Visschedijk, A., Vuollekoski, H., Vuolo, R., Wehner, B., Wildt, J., Woodward, S., Worsnop, D. R., van Zadelhoff, G.J., Zardini, A. A., Zhang, K., van Zyl, P. G., Kerminen, V.M., S Carslaw, K., and Pandis, S. N.: General overview: European Integrated project on Aerosol Cloud Climate and Air Quality interactions (EUCAARI) - integrating aerosol research from nano to global scales, Atmos. Chem. Phys., 11, 13061-13143, https://doi.org/10.5194/acp-11-13061-2011, 2011.

Kulmala, M., Lappalainen, H. K., Petäjä, T., Kurten, T., Kerminen, V.-M., Viisanen, Y., Hari, P., Sorvari, S., Bäck, J., Bondur, V., Kasimov, N., Kotlyakov, V., Matvienko, G., Baklanov, A., Guo, H. D., Ding, A., Hansson, H.-C., and Zilitinkevich, S.: Introduction: The Pan-Eurasian Experiment (PEEX) multidisciplinary, multiscale and multicomponent research and capacity-building initiative, Atmos. Chem. Phys., 15, 1308513096, https://doi.org/10.5194/acp-15-13085-2015, 2015.

Lappalainen H., Petaja T., Kujansuu J., Kerminen V.-M., Shvidenko A., Bäck J., Vesala T., Vihma T., de Leeuw G., Lauri A., Ruuskanen T., Lapshin V.B., Zaitseva N., Glezer O., Arshinov M., Spracklen D.V., Arnold S.R., Juhola S., Lihavainen H., Viisanen Y., Chubarova N., Chalov S., Filatov N., Skorokhod A., Elansky N., Dyukarev E., Esau I., Hari P., Kotlyakov V., Kasimov N., Bondur V., Matvienko G., Baklanov A., Mareev E., Troitskaya Y., Ding A., Guo H., Zilitinkevich S., and Kulmala M.: PanEurasian Experiment (PEEX) - A research initiative meeting the grand challenges of the changing environment of the northern Pan-Eurasian Arctic-boreal areas, Geography, Environment and Sustainability, 7, 13-48, 2014.

Lappalainen, H. K., Kerminen, V.-M., Petäjä, T., Kurten, T., Baklanov, A., Shvidenko, A., Bäck, J., Vihma, T., Alekseychik, P., Andreae, M. O., Arnold, S. R., Arshinov, M., Asmi, E., Belan, B., Bobylev, L., Chalov, S., Cheng, Y., Chubarova, N., de Leeuw, G., Ding, A., Dobrolyubov, S., Dubtsov, S., Dyukarev, E., Elansky, N., Eleftheriadis, K., Esau, I., Filatov, N., Flint, M., Fu, C., Glezer, O., Gliko, A., Heimann, M., Holtslag, A. A. M., Hõrak, U., Janhunen, J., Juhola, S., Järvi, L., Järvinen, H., Kanukhina, A., Konstantinov, P., Kotlyakov, V., Kieloaho, A.-J., Komarov, A. S., Kujansuu, J., Kukkonen, I., Duplissy, E.-M., Laaksonen, A., Laurila, T., Lihavainen, H., Lisitzin, A., Mahura, A., Makshtas, A., Mareev, E., Mazon, S., Matishov, D., Melnikov, V., Mikhailov, E., Moisseev, D., Nigmatulin, R., Noe, S. M., Ojala, A., Pihlatie, M., Popovicheva, O., Pumpanen, J., Regerand, T., Repina, I., Shcherbinin, A., Shevchenko, V., Sipilä, M., Sko- 
rokhod, A., Spracklen, D. V., Su, H., Subetto, D. A., Sun, J., Terzhevik, A. Y., Timofeyev, Y., Troitskaya, Y., Tynkkynen, V.P., Kharuk, V. I., Zaytseva, N., Zhang, J., Viisanen, Y., Vesala, T., Hari, P., Hansson, H. C., Matvienko, G. G., Kasimov, N. S., Guo, H., Bondur, V., Zilitinkevich, S., and Kulmala, M.: PanEurasian Experiment (PEEX): towards a holistic understanding of the feedbacks and interactions in the land-atmosphere-oceansociety continuum in the northern Eurasian region, Atmos. Chem. Phys., 16, 14421-14461, https://doi.org/10.5194/acp-1614421-2016, 2016.

Le Hir, G., Ramstein, G., Donnadieu, Y., and Godderis, Y.: Scenario for the evolution of atmospheric $\mathrm{CO}_{2}$ during a snowball Earth, Geology, 36, 47-50, 2008.

Leybman, M. O., Kizyakov, A. I., and Streleckaya I. D.: Yamal crater - new natural phenomenon of permafrost. Geology of seas and oceans. Articles XXI International Scientific Conference (School) on Marine Geology, 16-20 November 2015, Moscow, Russia, 4, 273-277, GEOS, Moscow, Russia, 2015.

Maeno, N.: The Science of Ice, Mir, Moscow, Russia, 231 pp., 1988 (Russian translation from Japanese).

Martin, S.: Ice stalactites: comparison of a laminar flow theory with experiment, J. Fluid Mech., 63, 51-79, 1974.

Melnikov, V. P. and Gennadinik, V. B.: Cryosophy: An outlook of the cold world, Earth Cryosphere (Kriosfera Zemli), 15, 3-7, 2011.

Melnikov, V. P., Spesivcev, V. I., and Kulikov, V. N.: About jet degassing of hydrocarbons as a source of ice growths on the shelf of the Pechora Sea, Results from basic research on the Earth cryosphere in Arctic and Subarctic, Nauka, Novosibirsk, Russia, 259-269, 1997.

Melnikov, V. P., Nesterov, A. N., Reshetnikov, A. M., Istomin, V. A., and Kwon, V. G.: Stability and growth of gas hydrates below the ice-hydrate-gas equilibrium line on the P-T phase diagram, Chem. Eng. Sci., 65, 906-914, 2010.

Melnikov, V. P., Gennadinik, V. B., and Broushkov, A. V.: Aspects of cryosophy: cryodiversity in nature, Earth Cryosphere (Kriosfera Zemli), 17, 3-11, 2013.

Milanković, M.: Mathematische Klimalehre und astronomische Theorie der limaschwankungen, in: Handbuch der Klimatologie, Bd. 1: Allgemeine Klimalehre, edited by: Köppen, W. and Geiger R., Borntraeger, Berlin, Germany, Russian Translation GONTI, Moscow, Russia, 1939.

Möhlmann, D. T. F.: Are nanometric films of liquid undercooled interfacial water bio-relevant?, Cryobiology, 58, 256-261, 2009.
Osokin, N.: Water sampling of the subglacial lake Vostok. Draft comprehensive environmental evaluation (revised), Institute of Geoecology. Arctic and Antarctic Research Institute, Russian Antarctic Expedition, St-Petersburg, Russia, 67 pp., available at: http://www.aari.aq/docs/water_sampling_lake_vostok. pdf (last access: 26 April 2018), 2003.

Petäjä, T., Järvi, L., Kerminen, V.-M., Ding, A., Sun, J., Nie, W., Kujansuu, J., Virkkula, A., Yang, X., Fu, C., Zilitinkevich, S., and Kulmala, M.: Enhanced air pollution via aerosolboundary layer feedback in China, Sci. Rep., 6, 18998, https://doi.org/10.1038/srep18998, 2016.

Pruppacher, H. R. and Klett, J. D.: Microphysics of clouds and precipitation, Kluwer, Dordrecht, the Netherlands, 954 pp., 1997.

Rosenfeld, D., Sherwood, S., Wood, R., and Donner, L.: Climate effects of aerosol-cloud interactions, Science, 343, 379-380, 2014.

Schaefer, K., Lantuit, H., Romanovski, V. E., Schuur, E. A. G., and Witt, R.: The impact of the permafrost carbon feedback on global climate, Environ. Res. Lett., 9, 085003, https://doi.org/10.1088/1748-9326/9/8/085003, 2014.

Shavlov, A. V., Dzhumandzhi, V. A., and Romanyuk, S. N.: Formation of spatially ordered structures by water drops in atmospheric clouds, Earth Cryosphere (Kriosfera Zemli), 15, 52-55, 2011.

Smith, L.: The New North: the World in 2050, Profile Books, London, UK, 2010.

Smith, S. J., Edmonds, J., Harting, C. A., Mundra, A., and Calvin, K.: Near-term acceleration in the rate of temperature increase, Nat. Clim. Change, 5, 333-336, 2015.

Tamisiea, M. E., Mitrovica, J. X., and Davis, J. L.: GRACE gravity data constrain ancient ice geometries and continental dynamics over Laurentia, Science, 316, 881-883, 2007.

Thoma, M., Mayer, C., and Grosfeld, K.: Sensitivity of subglacial Lake Vostok's flow regime on environmental parameters, Earth Planet. Sc. Lett., 269, 242-247, https://doi.org/10.1016/j.epsl.2008.02.023, 2008.

Vernadsky, V. I.: The chemical structure of the Earth's biosphere and its environment, Moscow, Russia, 340 pp., 1965.

Vlassov, A. V., Johnston, B. H., Landweber, L. F., and Kazakov, S. A.: RNA catalysis in frozen solutions, Dokl. Biochem. Biophys., 402, 207-209, 2005.

Yenikeyeff, S. M. and Krysiek, T. F.: The battle for next energy frontier: The Russian polar expedition and the future of Arctic hydrocarbons, Energy Comments, The Oxford Institute for Energy Studies, Oxford, UK, 2007. 